\title{
Predicaments and Approaches of Collaborative Education of Ideological and Political Education for College Students under the Background of "Internet Plus"
}

\author{
Wenjuan Liu \\ Shandong Xiehe University, Jinan, Shandong, 250109
}

Keywords: college students; Internet Plus; collaborative education

\begin{abstract}
The theoretical inquiry and practical exploration of the mechanism of collaborative education of ideological and political education in colleges and universities is of great significance to the specific echo of the party and the state building socialist universities with Chinese characteristics and striving to cultivate talents with both ability and integrity. Facing the current situation of the collaborative education mechanism of ideological and political education in colleges and universities, colleges and universities need to promote the "big thinker policy" pattern by optimizing the top-level design, construct an all-round education mechanism that fully utilizes various educational carriers, and establish and improve the coordination of ideological and political education in colleges and universities. The three aspects of the protection mechanism for educating people have been improved.
\end{abstract}

\section{Introduction}

General Secretary Xi Jinping emphasized at the 2016 National Conference on Ideological and Political Work in Colleges and Universities that "all kinds of courses and ideological and political theory courses should be peered together to form a synergistic effect”. This point from the point of view of all kinds of courses and ideological and political theory courses to peers, and further put forward the new requirements for the ideological and political education of colleges and universities to develop together. At the same time, it also shows that the process of building a socialist university with Chinese characteristics is inseparable from the theoretical exploration and practical exploration of the cooperative education system. Facing the new problems in the new era, the new era, and the new field, colleges and universities should proceed from the basic task of "learning from the trees", dig deeper into the ideological and political education resources in various courses, and give full play to the actual effectiveness of ideological and political education. We will earnestly strengthen the educational philosophy and cultivating responsibilities of all teachers, strive to improve the mechanism of collaborative education, and realize the complementary advantages, mutual cooperation and shortcomings between the various subjects, so that all courses and ideological and political theory courses To peer, so as to truly form a "new process, all-round education" new situation.

\section{The Importance of Constructing a Coordinated Education Mechanism for Ideological and Political Education in Colleges and Universities}

At present, under the correct guidance of the Party Central Committee's policies, the overall situation of the construction of ideological main positions is relatively good. Marxist colleges in colleges and universities are not only important positions for preserving the mainstream ideology in colleges and universities, but also the forward positions of ideological work in China and the main channels for ideological and political education in colleges and universities. They play an important role in cultivating morality, scientific research, and talent cultivation, and shouldering shoulders. It is an important task to study the inheritance of Marxism, cultivate and carry forward the core values of socialism, and provide talent guarantee and intellectual support for the realization of the Chinese dream of the great rejuvenation of the Chinese nation. It is specifically covered by all the members 
of the ideological and political theory course of colleges and universities, and it guides and edifies the university students' world outlook, outlook on life and values. At the same time, through the profound explanation and careful explanation of the basic theoretical knowledge of Marxism, they can use them. The latest theoretical results of Marxism in China are armed. In the construction of specific ideological and political education disciplines, "it is to closely follow the important speech of General Secretary Xi Jinping, to revolve around the new ideas, new ideas and strategies of the Party Central Government, to strengthen the selection of topics, strengthen resource integration, organize collective research, and launch more. More research results are based on the country's economic and social development practice, based on the actual work of ideological and political education in colleges and universities, gaining position and self-confidence in serving the country's economic and social development, embodying value and earning respect in serving students' healthy growth. Enhance the appeal, credibility and influence of research. It is necessary to adhere to the goal of building China and China, focusing on the construction of ideological and political education disciplines with Chinese characteristics, Chinese style and Chinese style, constantly exploring new materials, discovering new problems, and proposing New ideas, construct new theories, and build a Chinese discourse system for ideological and political education". However, the current domestic and international political and economic environment is more complicated, the society is facing a dramatic transformation, various social contradictions are superimposed, social interest conflicts are intensifying, group events are increasing, interest pattern adjustment resistance is increasing, and our mainstream ideology is building. And the construction of ideological and political education disciplines has been affected to a certain extent, and it has always faced the impact and erosion of western capitalist society ideology. Especially in the context of economic globalization, the political, economic, and cultural exchanges between countries have become increasingly close. Some Western countries have attempted to use the "sugar-coated cannonballs" of cultural exchanges to carry out "color revolutions" on China, and various "anti-horse" and "reverse" The voice of the society is one after another. In addition, the continuous development of network digital technology and mobile internet has brought about new changes in thinking patterns and cognitive methods of contemporary college students. Therefore, in this social environment, colleges and universities should update the ideological and political education concept, deeply explore the resources for ideological and political education in various disciplines, and fully coordinate the cultivation of human resources in various disciplines. Grass-roots Marxist colleges should actively explore synergy theories and collaborative practices. , Form a joint force to resist the ideology of Western capitalist society, and jointly defend and disseminate Marxism in a clear-cut manner to jointly resist the negative influence brought about by Western culture, and strive to improve the effectiveness of ideological and political education in colleges and universities and actively maintain the mainstream ideological position in colleges and universities.

\section{Realistic Difficulties and Causes of Collaborative Education Mechanism for College Students' Ideological and Political Education}

In terms of system construction, it is necessary to build a perfect, efficient and stable ideological and political education collaborative education mechanism that requires the cooperation of the theoretical teaching department, the party and government, the Communist Youth League and the student work department. However, the actual situation is often that each functional department has its own functions, lacks communication, and it is difficult to form a joint force. The students' understanding of ideological and political education only stays at the level of learning of political theory, and does not view ideological politics from the height of promoting its all-round development. Education leads to a disconnect between theoretical study and real life, and the separation of practice and ability.

In terms of content construction, the construction of a sound, efficient, and stable ideological and political education education system should integrate and optimize all educational resources of the university so as to make it a systematic ideological and political education resource. However, the actual situation is often that the disciplines do not support each other and do not support each other, 
and it is difficult to form a synergistic effect among the disciplines. In the long run, ideological and political education will be isolated, and students' attitudes to them will naturally be indifferent to the typical performance. It is the attitude of students when they study ideological and political theories far less than when they study professional courses.

Analysis from a theoretical level can be attributed to the lack of understanding and recognition of synergies among the various functional departments and teaching departments. It is still viewed from a traditional perspective on ideological and political education, and it is simply understood as the explanation and propaganda of political theory, or General understanding of moral education for students; analysis from a practical level can be attributed to the lack of synergy among various departments, and the root cause lies in the fact that the actions of various departments are subject to established systems and mechanisms. It is difficult to break through.

\section{Solutions to the Cooperative Educational System of College Students' Ideological and Political Education}

Through institutionalized norms, various departments realized that ideological and political education is not a simple theoretical study, but should be accomplished through mutual cooperation among various departments. In the practice of education and teaching, each department is regarded as In the field of ideological and political education, the various teaching and management departments of the school must cooperate and form joint forces to effectively improve the quality of ideological and political education.

In view of the lack of collaboration among educational resources, the content of ideological and political education is too monotonous, and the phenomenon of students' indifferent attitude towards ideological and political education should be "corrected" by formulating educational resource optimization mechanisms. In terms of content, the integration of cultural knowledge education, psychological quality education and artistic aesthetic education creates a synergistic effect, enabling students to feel from the heart the ideological and political education for their spiritual nourishment and humane care, recognizing that being a college student is only a matter of political quality. Only after the comprehensive and coordinated development of cultural quality and psychological quality can we be able to respond to fierce competition in the 21st century and shoulder the heavy responsibility for the great rejuvenation of the Chinese nation.

Colleges and universities should make full use of the rich and varied carriers and establish a comprehensive and multi-angle ideological and political education system. First, colleges and universities should make full use of traditional carriers and modern carriers to give full play to their respective advantages. The traditional carrier of ideological and political education in colleges and universities has conversational talks, meeting discussions, and theoretical education. The modern carrier is a carrier that conforms to the characteristics of the times and is continuously created under the new historical conditions. It mainly includes cultural carriers, activity carriers, and media carriers. In the process of carrying out ideological and political education, it is necessary to make full use of traditional carriers and modern carriers to bring into play the different advantages and characteristics of the two, and through the integrated use of different carriers to enhance the breadth and penetration of education and comprehensively improve the thinking of college students. Political accomplishment. Second, universities should flexibly use a variety of carriers based on actual conditions. In the specific education practice process, the education subject needs to consider the situation of the educated person, and can not use the same carrier to carry out ideological and political education, but must vary from person to person, attach importance to individualized features, and select the appropriate carrier according to the students' different characteristics. If science and engineering students generally do not like to face only boring words and various regulations, the traditional theoretical education carrier cannot achieve the expected results. Then, college educators should select popular media carriers and activities according to the characteristics of students. Carriers give full play to the advantages and characteristics of these two types of carriers and improve the effectiveness of ideological and political education. In short, both the traditional carriers and the various carriers in the modern carriers have their own advantages and 
disadvantages. In the process of concretely carrying out the ideological and political education practice activities, these carriers must be combined and matched to use a variety of carriers in a comprehensive manner. To achieve complementary advantages and organic convergence between carriers.

\section{Conclusion}

The ideological and political education synergistic education mechanism of colleges and universities as a brand-new educating mechanism is in line with the overall requirements of the Party for the ideological and political education after the 18th National Congress, and has strong reality and innovation. Of course, there are still some problems in the practical education practice, and they are facing some difficulties. However, this is not scary. The development of any new things is not easy and it is difficult to avoid rough and ups and downs. The author believes that the vitality of new things is powerful. It is believed that in the near future, under the influence of the ideological and political education education system, it will certainly be able to form a new situation in ideological and political education work!

\section{Acknowledgements}

2016 Social Sciences Planning Research Project of Shandong Province (Specialization of Ideological and Political Education in Colleges and Universities) "Study on Collaborative Innovation of Ideological and Political Education for College Students in the "Internet Plus" Age"

Project Number: 16CKSJ16

\section{References}

[1] Feng Gang. Four Key Points for the Innovative Development of Ideological and Political Education [J]. Teaching and Research, 2017, (1).

[2] Sun Jian. College Ideological and Political Work Mechanism and Practice Reflection from the Perspective of Collaborative Education [J]. School Party Building and Ideological and Political Education in Colleges and Universities, 2014(12):63.

[3] Ma Chi Ke. On the Cooperative Mechanism of Ideological and Political Education [J]. Jianghan Forum, 2008.4.

[4] Zhang Yaocan, Chen Wanbai. Principles of Ideological and Political Education [J]. Higher Education, 2001: 181.

[5] Zheng Guangxiang. The Construction of Cooperative Mode of Ideological and Political Education in Colleges and Universities[J]. Journal of Harbin University, 2014(25):137. 